\title{
Bibliometric Analysis of the Potential of Technologies in the Humanitarian Supply Chain
}

\author{
Mauricio Argumedo-García ${ }^{1}$, Katherinne Salas-Navarro ${ }^{2, * \mathbb{D}}$, Jaime Acevedo-Chedid ${ }^{1}$ \\ and Holman Ospina-Mateus ${ }^{1}$ (D) \\ 1 Department of Industrial Engineering, Universidad Tecnológica de Bolívar, Cartagena 131001, Colombia; \\ mauricio.argumedog@gmail.com (M.A.-G.); jacevedo@utb.edu.co (J.A.-C.); hospina@utb.edu.co (H.O.-M.) \\ 2 Department of Productivity and Innovation, Universidad de la Costa, Barranquilla 080002, Colombia \\ * Correspondence: ksalas2@cuc.edu.co
}

Citation: Argumedo-García, M.; Salas-Navarro, K.; Acevedo-Chedid, J.; Ospina-Mateus, H. Bibliometric Analysis of the Potential of Technologies in the Humanitarian Supply Chain. J. Open Innov. Technol. Mark. Complex. 2021, 7, 232. https:// doi.org/10.3390/joitmc7040232

Received: 25 August 2021

Accepted: 4 November 2021

Published: 1 December 2021

Publisher's Note: MDPI stays neutral with regard to jurisdictional claims in published maps and institutional affiliations.

Copyright: (c) 2021 by the authors. Licensee MDPI, Basel, Switzerland. This article is an open access article distributed under the terms and conditions of the Creative Commons Attribution (CC BY) license (https:/ / creativecommons.org/licenses/by/ $4.0 /)$.

\begin{abstract}
This study presents a bibliometric analysis of research on technology in the humanitarian supply chain. The methodology includes performance analysis and science mapping to explore the application of technologies in humanitarian supply chains. This paper contributes to the literature by examining the most influential authors, trends, journals, countries, institutions, and the recent humanitarian supply chain collaboration. The information presented in this research was obtained with the Scopus database. The study identified 342 documents after applying filters to screen for duplicates and manuscripts unrelated to the topic. The articles were analyzed using MS Excel and VOSviewer. The research provides an overview of state of the art showing a high collaboration between the authors Ramesh A. and Kabra C, and the most relevant institutions were the Griffith Business School and the Delft University of Technology. Journal of Humanitarian Logistics and Supply Chain Management and Journal of Disaster Research were the most productive journals. The terms analysis shows that "disasters", "disaster prevention", "humanitarian logistics", and "human" are the most used keywords. The study identifies future research lines related to the interaction between critical technologies to deliver real benefits to the humanitarian supply chain. As a result, it proposes integrating the significant contributions of new technologies, such as blockchain, big data, artificial intelligence, 3D printing, virtual and augmented reality, and the social media relief phase following the disaster. It also indicates gaps in knowledge in terms of research related to human-made disasters and health emergencies.
\end{abstract}

Keywords: humanitarian supply chain; digital technologies; humanitarian logistics; disaster prevention

\section{Introduction}

A bibliometry is an analytical method used to obtain measurable results from a scientific production [1]. It is also considered a means to analyze publications that apply statistical methods, to learn about a specific topic, and to internally quantify the scientific process. The information and analysis obtained on scientific production can help discover the development of a particular subject, different research fields, and future research opportunities. It is also helpful for forecasting and decision-making.

Among the elements that are usually considered within a bibliometric analysis, there is institutional affiliation, dates of publication, journals, books, authors, citations, keywords, titles, and abstracts, among other sources of information included in the documents [2]. These elements are relevant to obtain the evidence of the results in a research field; thus, these will be used to achieve the purpose of this study.

Bibliometric analysis is considered a validated research technique in several fields, including business, technology, and infometrics [3]. In this study, a bibliometric review was performed in the humanitarian supply chain technologies to learn about the most outstanding publications and to review their evolution and the studies in progress. 
According to global statistics, approximately 60,000 people die annually due to natural disasters ( $0.1 \%$ of deaths worldwide) [4]. The humanitarian supply chain participates in activities related to preparing and managing the resources required (including materials, information, and financing) during natural disaster relief efforts. The main actors are from different organizations (private organizations, agencies, and non-governmental organizations). The collaboration and cooperation of these actors are fundamental factors to guarantee the success of relief operations $[5,6]$.

A feature of this century is the high frequency and intensity of phenomena such as hurricanes, droughts, floods, and tsunamis, among others, which are for the most part related to climate change in one way or another. At the same time, the planet is immersed in armed conflicts, wars, and terrorism, which produce human-made disasters. Consequently, every continent faces such humanitarian emergencies with millions of victims who find themselves dependent on external assistance, making humanitarian assistance a matter of international importance [7].

Humanitarian logistics is a modern concept that focuses on obtaining adequate resources for regions or areas that have suffered the impact of natural or human-made disasters. The principal objective is controlling the resources for the affected areas, extending the useful lives of the means necessary for survival, and ensuring the affected population's safety. Humanitarian logistics have a crucial role in facilitating coordination between the various actors. They participate in disaster relief and offer additional assistance, such as food, medical care, water, and shelter. Based on these requirements, technologies have acquired significant importance for the effects of covering all types of emergencies and are currently used in a broad range of fields related to disaster management, enabling the use of smart/intelligent methods and efficient and effective logistics operations.

The humanitarian system presents important challenges. At the same time, new technologies, partners, and concepts enable humanitarian actors to understand and address problems quickly and effectively. This condition has generated increased interest in "humanitarian innovation" by organizations. A better understanding of the potential and purpose of the innovation cycle and an innovative mindset can bring significant benefits to the humanitarian system [8]. Another research study developed by the International Federation of Red Cross and Red Crescent Societies conducted a theory-driven, bottom-up innovation search process for the real-life humanitarian problem of recurring floods in Indonesia [9].

Some research related to applications in the Humanitarian Supply Chain (HSC) has been developed. A literature review of bigdata supporting the humanitarian supply chain strategies $[10,11]$ identifies benefits related to humanitarian logistics, remote sensing, information security, and the use of social media during humanitarian operations. Another study presents a literature review of the communication challenges during a disaster that recognizes the importance of including radio operations in emergency operation plans [12]. These studies focus on applications such as big data and radio operations but do not consider all the technologies applied in the humanitarian supply chains.

This research also considers aspects related to the development of open innovation. The topic of humanitarian logistics can expand the funnel of knowledge and promote future studies. For example, technological applications, computational developments, and communications prove that it is possible to prevent and face unwanted events due to natural conditions, catastrophes, and conflicts. Development in the area generates significant benefits for human well-being [13].

In this context, this study was conducted to evaluate the available literature on the humanitarian supply chain that focused on the potential of technologies, and to establish the most influential authors, institutions, articles, countries, regions, and future studies. The bibliometric research includes scientific production and trends, principal authors, institutions, journals, articles, countries, regions, collaboration, analysis of citations, and future studies. The objectives of this study are (a) to present a literature review of the application of technologies in the humanitarian supply chain developed since 1983; (b) to identify 
the technologies applied and the future research lines; (c) to identify the main research clusters from the analysis of co-citations; (d) to identify the impact of the contribution of the technology's applications in the innovation process within the humanitarian supply chain. This research also includes an insight into the open innovation related to technological applications, computational developments, and communications in the humanitarian supply chain.

The paper is organized as follows. Section 2 presents the applied methodology and the data collection procedure. Section 3 includes the results of the performance analysis and science mapping. The analysis and discussion of the scientific production, trends, authors, journals, institutions, countries, citations, and impact of the publications are also presented. Section 4 provides the conclusions, implications, and future research topics.

\section{Materials and Methods}

The proposed bibliometric analysis allows a review of the previous research and generates an overview of the technologies applied to humanitarian supply chains. This study also includes a network analysis applied to the dataset to identify collaboration networks between authors, countries, and territories. This approach incorporates the most influential research analysis based on the citations and the representative terms associated with humanitarian supply chains. The bibliometric analysis method was selected for the following reasons. First, this approach allows the revision of a large number of publications, comprehensive information, and metadata to show a performance analysis [14]. Second, the applied method analyzed collaborative networks, evolution over time, citations, and most used terms. Third, the visualization of the research results facilitates the understanding and analysis of information for readers [15].

This bibliometric analysis is based on the literature recorded in the Scopus related to the use of potential technologies in the humanitarian supply chains. The search strategy was established according to the bibliometric analysis developed by Reyes, et al. [16] and MezaPeralta, et al. [17]. This approach included the relationships between authors, countries, institutions, keywords, and citations [18,19]. This database was selected because it is the largest database of peer-reviewed citations and abstracts of scientific literature, articles, and conferences [20]. This research seeks to answer the following questions. Which are the latest research areas? What are the major collaborative networks and contributions? Who are the leading researchers/experts? Is the full range of leading-edge research being discovered?

In the initial stage of the search, the keywords used were "humanitarian supply chain" and "technologies". These terms were input into the Scopus database to obtain a first list of publications that contained these three keywords in their title, abstract, and keywords. The key terms for each keyword were identified, as illustrated in Table 1.

Table 1. List of keywords used for the literature search.

\begin{tabular}{cr}
\hline Groups & Key Terms \\
\hline $\begin{array}{c}\text { Humanitarian } \\
\text { supply chain }\end{array}$ & $\begin{array}{c}\text { Humanitarian supply chain, humanitarian supply chain management, humanitarian logistics, humanitarian } \\
\text { logistic, humanitarian logistics management, humanitarian inventory management, humanitarian relief logistics, } \\
\text { humanitarian operations, HSCM, emergency operations, disaster relief operations, disaster operations. } \\
\text { Technologies }\end{array}$ \\
$\begin{array}{r}\text { Technologies, technology, disruptive technologies, disruptive technology, digital technologies, digital technology, } \\
\text { humanitarian aid networks, digital, technology adoption, technologies adoption. }\end{array}$ \\
\hline
\end{tabular}

Subsequently, a new search equation was defined, combining both groups of terms with the Boolean operator "AND" and between categories using "OR." The study included scientific articles, books, reports, book chapters, and conferences. The publication date was not limited to a specific period. Lastly, the publications were screened to exclude articles unrelated to the topic, as illustrated in Figure 1. If the exact search is done for a different date, the results will change because the database is continuously updated, producing minor changes over time [21]. 


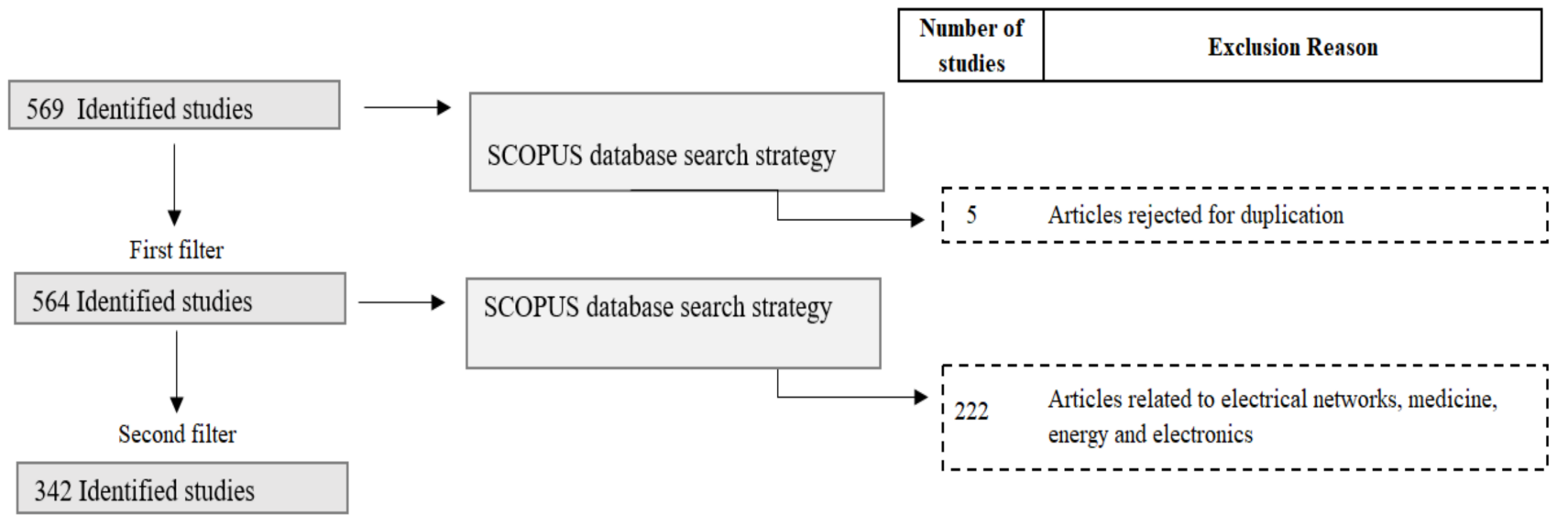

Figure 1. Selection process for including articles.

Five hundred sixty-nine publications were obtained using the equation referenced in Table 2, and they were screened using various exclusion criteria. The first exclusion filter identified all duplicate articles (5 manuscripts). The second filter was for articles that were unrelated to the topic (222 articles). The articles that were excluded were related to electrical engineering, medicine, energy, and electronics that included terms such as "emergency operations" in the context of medicine or references to terms such as "digital" in articles on electronics and electricity. Other articles unrelated to the topic were identified by reading the title and the abstract of all the manuscripts after applying the first filter. The result of the number of publications that were included in this bibliometric study was 342 articles published between 1983 and 2021. All the search results were included in the study without exception. Figure 1 summarizes the search and screening process of the information related to the subject taken from Scopus. By type of document, the majority are conference papers and conference reviews (conference $=165$ ), followed by 146 articles in journals. The other document types are books and book chapters.

Table 2. Summary of the methodology used.

\begin{tabular}{|c|c|}
\hline Sources & $\begin{array}{l}\text { Relevant Articles, Books, and Conference Proceedings That the Content Was Related between } \\
\text { "Humanitarian Supply Chain" and "Technologies" }\end{array}$ \\
\hline Type of analysis & Qualitative and quantitative analysis \\
\hline Period & 1984-2020 \\
\hline Database & Scopus \\
\hline Search terms & 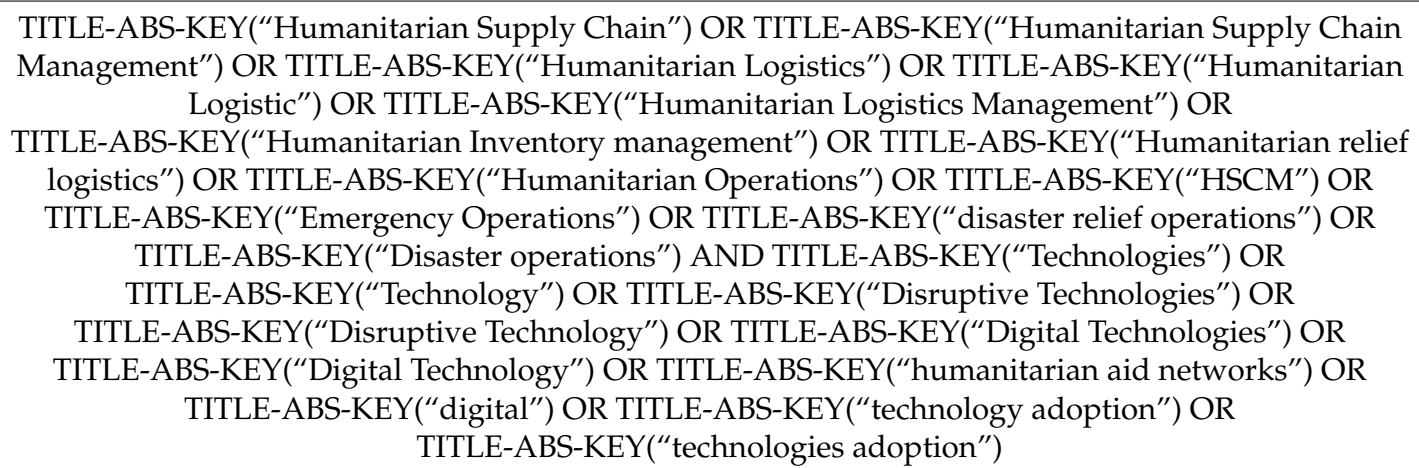 \\
\hline Total-/documents & 342 \\
\hline
\end{tabular}

Table 2 describes the variables and the methodology used, which were unit of measure, type (qualitative and quantitative), period (unlimited), database (Scopus), and search terms. The search results on Scopus Database contain information on the publication date, authors, 
affiliation, title, abstract, journals, and keywords, which were managed in an MS Excel spreadsheet. The network analysis was carried out using the VOSwierver software, which identifies relationships between authors, countries, co-citations, and terms. The analysis of this information allows mapping of the concurrency and distance/relationship between aspects. The maps are interpreted using clustering and assigning color codes, sizes, and distances between the assessed terms.

\section{Results}

Bibliometrics combines two main procedures, performance analysis and science mapping [22]. Performance analysis is used to study trends in scientific research based mainly on research centers, journals, or regions [23]. The study of these statistics enables viewing the trends in research, including the most influential authors and the most cited references [24]. In contrast, science mapping provides a spatial representation of how the various participants are related [25]. In this bibliometric study, the following aspects were reviewed, (1) scientific production and trends, (2) authors and their work, (3) journals of publication, (4) distribution by geography, institutions, and collaboration, (5) analysis of citations, (6) analysis of co-citations (networks), (7) theme categories, and (8) analysis of terms.

\subsection{Scientific Production and Trends}

Evaluating the publications included in this bibliometric study allows knowing the progress, development, and research trends in the potential of technologies in the humanitarian supply chain. The first publication was in 1983. From 1983 to 2004, there were 27 publications, with an average of 2.3 publications per year (see Figure 2). The number of publications started to expand in 2003 (after the World Trade Center and the Tsunami in the Indian Ocean). Then, this natural disaster is directly correlated with the increase in publications produced in 2005, which was the year with the most publications on this topic.

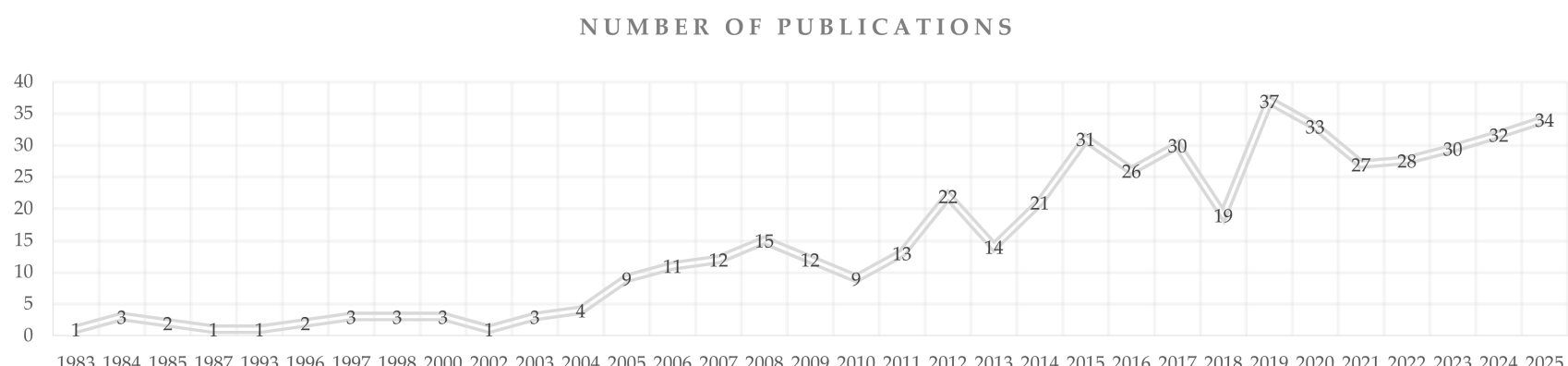

(a)

CUMMULATIVE NUMBER OF PUBLICATIONS

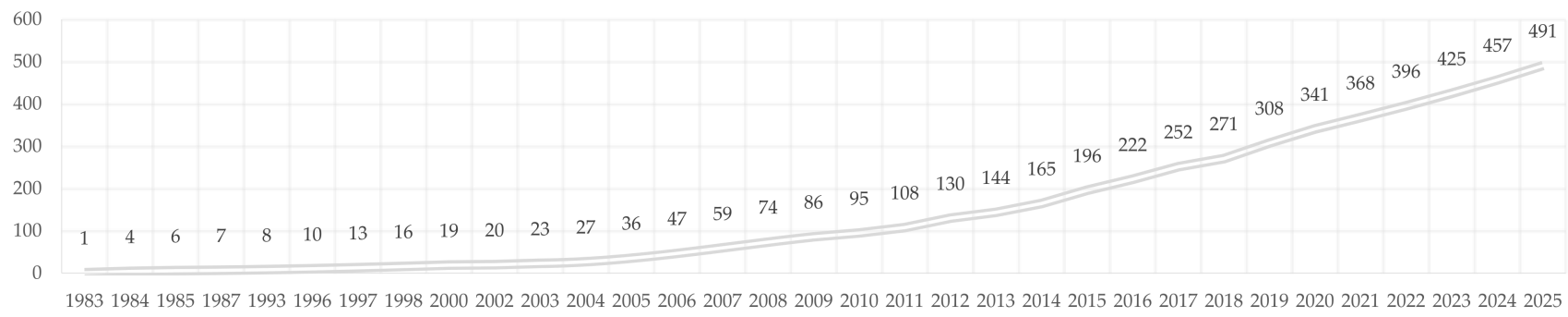

(b)

Figure 2. Forecast of (a) the number of publications per year and (b) the cumulative number of publications on the subject to 2025. Source: Scopus (2020). 
In 2006, another peak was found in the number of publications, just a year after Hurricane Katrina. Other natural disasters in 2010 and 2011 (an earthquake in Haiti and a tsunami in Japan) also produced a peak in 2012, with 22 publications (the highest number of publications per year). The period from 2005 to 2012 is the one that presents the most significant exponential growth in the number of publications on the topic. In 2015, the number of publications also increased to 31 papers related to applications of the Internet of the Things (IoT), Geography Information Systems (GIS), social media, cyber security, and rescue robots. Another peak was identified in 2019, with 37 publications related to big data, social media, blockchain, and risk management applied to humanitarian disasters.

The publication trends of technologies in the humanitarian supply chain were analyzed using the exponential smoothing method. The results indicate that the number of publications in the next five years would be around 30 articles per year, equivalent to a cumulative total of 491 publications until 2025. Then, the current health emergency produced by COVID-19 has generated an increase in the number of publications. The socioeconomic consequences of the lock-down measures of recent months and the crisis itself have had significant effects on the operation of supply chains, whose effectiveness is now more necessary than ever. For this reason, the increase of publications evidences the growing interest of researchers.

\subsection{Authors and Collaboration}

One thousand thirty-five different authors developed the 342 manuscripts. A total of $94.5 \%$ of the authors are associated with a single publication on the subject; $5 \%$ are associated with two publications; $0.1 \%$ with three publications; $0.29 \%$ with four or more publications; $0.1 \%$ of the publications are conferences.

Table 3 displays the top ten authors in terms of the number of publications on the subject, based on the total number of publications. Ramesh, A. is the author with the major number of publications (six publications) on humanitarian supply chain technologies, followed by Kabra, G. and Tatham, P. with five publications, Wu, Y., with three publications, and the remaining authors with two publications. The range of average citations by publication is between 0 and 55 citations. Kabra, G. and Tatham, P. are the authors with the most publications as first authors (5).

Table 3. Top ten most productive authors with publications on the subject. Source: Scopus (2020).

\begin{tabular}{ccccccc}
\hline No. & Author & Country & $\begin{array}{c}\text { Number of } \\
\text { Publications }\end{array}$ & Total Cites & $\begin{array}{c}\text { Average Citation Per } \\
\text { Document }\end{array}$ & $\begin{array}{c}\text { Number of Publications } \\
\text { as the First Author }\end{array}$ \\
\hline 1 & Ramesh, A. & India & 6 & 99 & 16.5 & 0 \\
2 & Kabra, G. & India & 5 & 87 & 17.4 & 5 \\
3 & Tatham, P. & Australia & 5 & 57 & 11.4 & 5 \\
4 & Akhtar, P. & New Zealand & 3 & 119 & 39.6 & 0 \\
5 & Wu Y. & Singapore & 3 & 19 & 6.3 & 0.66 \\
6 & Prasanna, R. & Sri Lanka & 3 & 32 & 44.5 & 0 \\
7 & Amditis A. & Australia & 2 & 89 & 47.0 & 0 \\
8 & Cai G. & United States & 2 & 94 & 55.0 & \\
9 & Casoni M. & Italia & 2 & 110 & 5.5 & \\
10 & Chang C.-L. & United States & 2 & 11 & & 0 \\
\hline
\end{tabular}

The average number of publications by the author is 1.1 . A total of $12 \%$ of the publications are by one author, $24.3 \%$ have two authors, and $63.7 \%$ have more than three authors. A total of $85 \%$ of the publications have more than two authors, which implies that many publications are co-authored. There are close relations between authors, contributing to a greater collaboration in the future [26].

The authors with the highest number of publications are Ramesh A., and Kabra G. Their research focuses on humanitarian logistics, disaster relief, placement, and assignment. They studied the facilitators to improve information and communication technologies [27], 
speed and flexibility in the humanitarian supply chain [28], and the problems of information and communication technologies in the humanitarian supply chain [29-31]. Similarly, Tatham, P. studied humanitarian logistics, disaster relief [32], location-assignment [33,34], supply chain management, management research, 3D printing [35], spare parts [36], and manufacturing technology.

The cooperation network between authors was obtained using the VOSviewer software, and the result is shown in Figure 3. The connections represent the cooperation between the authors, and the color scales show the collaboration groups. According to this result, Caunhye, A.M is the author who shows the authors' greatest cooperation. Ramesh, A. and Kabra, C. showed strong cooperation due to the affinity in the research themes (humanitarian logistics, disaster relief, location, and assignment) and the country of affiliation (India). Tatham, P. and Adjerid, I. show a close cooperative relationship, as do Yang, H. and Duran S.

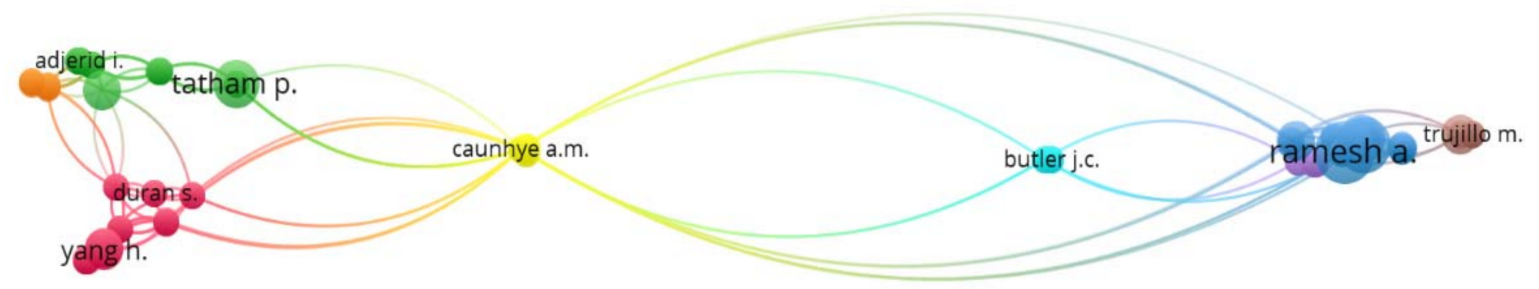

Figure 3. Collaboration networks between authors on the subject. Source: VOSviewer (2020).

\subsection{Journals Publishing on Humanitarian Supply Chain Research}

A total of 342 studies were published in 123 different journals. These publications indicate a high level of interest in the subject of journals with an SJR-2019 and H-Index-2019 (See Table 4 ). A total of $69.2 \%$ of the journals published a single article, $26.7 \%$ published two articles, $3.3 \%$ published between three and ten articles, and only one journal published more than ten articles on the subject. Table 4 shows the information on the top-five of the most active journals that publish on the subject. These five journals (1.5\% of all journals) have published $10 \%$ of all publications.

The most influential journals in this field are the Journal of Humanitarian Logistics and Supply Chain Management, with 15 publications, followed by the Journal of Disaster Research and Proceedings of SPIE, and the International Society for Optical Engineering, with six publications.

The Journal of Humanitarian Logistics and Supply Chain Management was a journal created to publish articles related to "humanitarian logistics and supply chain management," making it the most relevant journal in terms of the number of publications. In 2020, this journal won the "Emerald Literati Awards" to recognize its contributions to scientific knowledge. The award was granted to publish "Outsourcing of humanitarian logistics to commercial logistics service providers: An empirical investigation." This study covers the gaps in the humanitarian literature related to the specific factors of the context for outsourcing humanitarian logistics through empirical research on this topic. It is one of the first studies to empirically assess the potential of outsourcing humanitarian logistics during the stages of a disaster. It is consequently highly correlated with the purpose of this bibliometric study, which leads to considering the Journal of Humanitarian Logistics and Supply Chain Management as the most productive journal of this subject. The performance shows promising results in average citations per document, with 332 citations from 81 documents published between 2016 and 2019. 
Table 4. Top five most active journals on the subject. Source: Scopus (2020).

\begin{tabular}{|c|c|c|c|c|c|}
\hline No & Journal & $\begin{array}{l}\text { Number of } \\
\text { Documents }\end{array}$ & SJR-2020 & H Index-2020 & Subject Area and Category \\
\hline 1 & $\begin{array}{l}\text { Journal of Humanitarian } \\
\text { Logistics and Supply } \\
\text { Chain Management }\end{array}$ & 15 & 0.7 & 25 & $\begin{array}{l}\text { business, management, and accounting } \\
\text { management information systems } \\
\text { decision sciences } \\
\text { management science and operations } \\
\text { research }\end{array}$ \\
\hline 2 & $\begin{array}{l}\text { Journal of Disaster } \\
\text { Research }\end{array}$ & 6 & 0.33 & 18 & $\begin{array}{c}\text { engineering } \\
\text { engineering (miscellaneous) } \\
\text { safety, risk, reliability, and quality }\end{array}$ \\
\hline 3 & $\begin{array}{l}\text { Proceedings of SPIE-The } \\
\text { International Society for } \\
\text { Optical Engineering }\end{array}$ & 6 & 0.19 & 176 & $\begin{array}{c}\text { computer science } \\
\text { computer science applications } \\
\text { engineering } \\
\text { electrical and electronic engineering } \\
\text { materials science } \\
\text { electronic, optical, and magnetic materials } \\
\text { mathematics } \\
\text { applied mathematics } \\
\text { physics and astronomy } \\
\text { condensed matter physics }\end{array}$ \\
\hline 4 & Procedia Engineering & 5 & 0.32 & 74 & $\begin{array}{c}\text { engineering } \\
\text { engineering (miscellaneous) }\end{array}$ \\
\hline 5 & $\begin{array}{l}\text { Geo-Information for } \\
\text { Disaster Management }\end{array}$ & 2 & 0.11 & 2 & $\begin{array}{l}\text { earth and planetary sciences } \\
\text { geotechnical engineering and } \\
\text { engineering geology }\end{array}$ \\
\hline
\end{tabular}

\subsection{Geographic, Institutional Distribution and Collaboration}

\subsubsection{Countries and Territories}

The publications related to technologies in the humanitarian supply chain are from 51 different countries. Of the total countries, 21 are in Europe, 20 in Asia, 5 in Africa, 5 in America, and 1 in Oceania. Of the total articles (342), Asia has the greatest number of publications at 31.5\%, followed by Europe and America with 104 and 101 publications, respectively. The remaining publications are distributed among Oceania and Africa, which were the continents with the smallest number of publications.

Forty-one countries (80\%) produced eight or less publications. Five countries (10\%) produced between 10 and 13 publications, and five countries (10\%) produced between 14 and 85 publications. The country with most publications on the subject is the United States $(n=85)$, followed by China $(n=24)$, Germany $(n=20)$, and India $(n=20)$. Figure 4 shows the top ten countries and regions with the greatest article production.

According to the World Intellectual Property Organization, the United States and the United Kingdom are ranked in third and fifth place, respectively, in the "2019 Global Innovation Index." India and China have displayed substantial progress and have become leaders in their regions. The leading indicators assessed to calculate this index were associated with the development of applications for mobile phones and exports of high technology. According to the 2019 edition of the Global Innovation Index, except for Italy and Australia, the top 10 countries with the most significant contributions to technologies for the humanitarian supply chain, which are shown in Figure 4, are among the top 20 most innovative countries in the world [37].

Figure 5 displays the co-authorship research networks between countries and regions. The network shows the countries and territories with more than one publication on the subject. The countries or regions that are not related to others were not included in the network. The size of the circles represents the number of publications, and the links indicate collaboration between authors from different countries. 


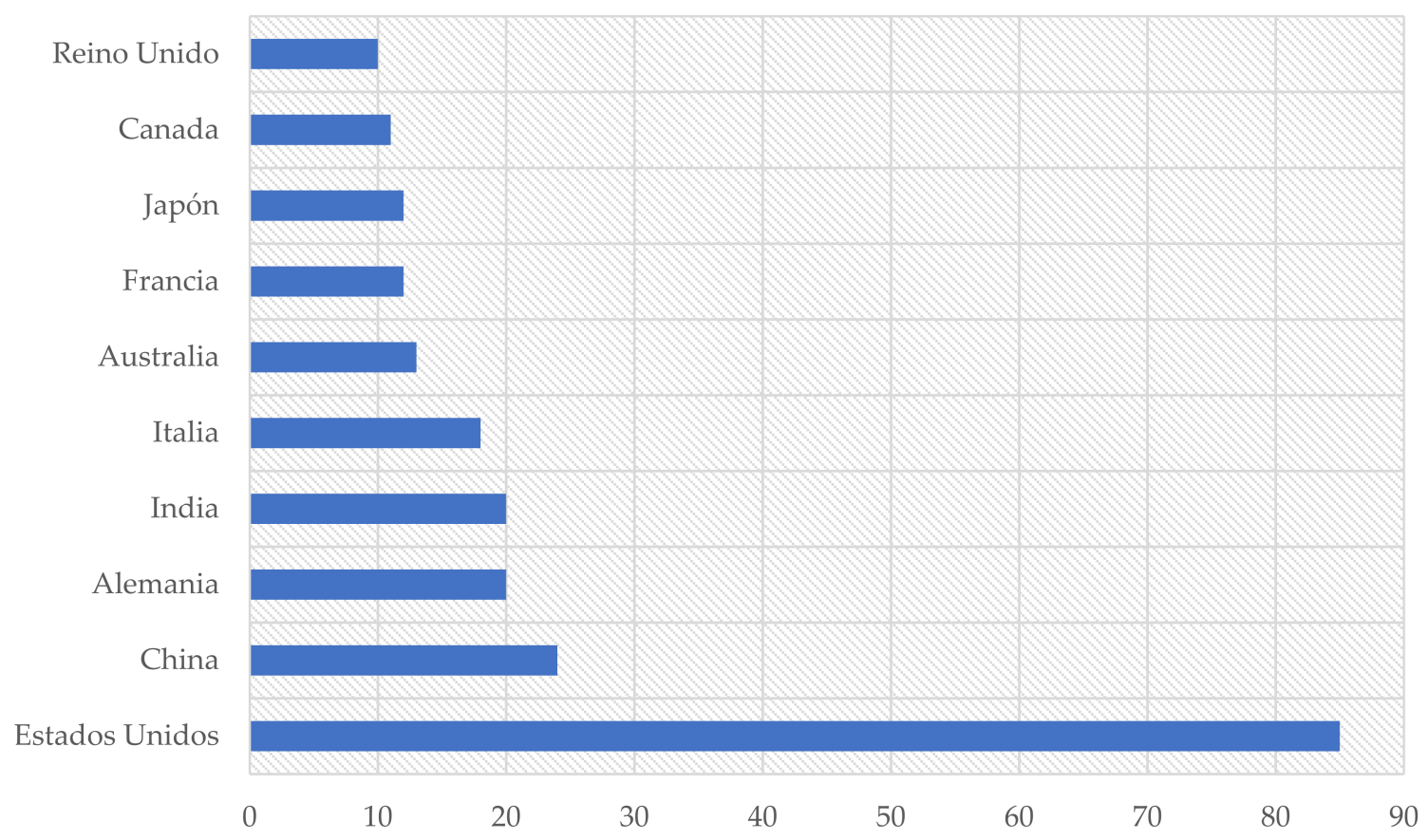

Figure 4. Top 10 countries with most publications on the subject. Source: Scopus (2020).
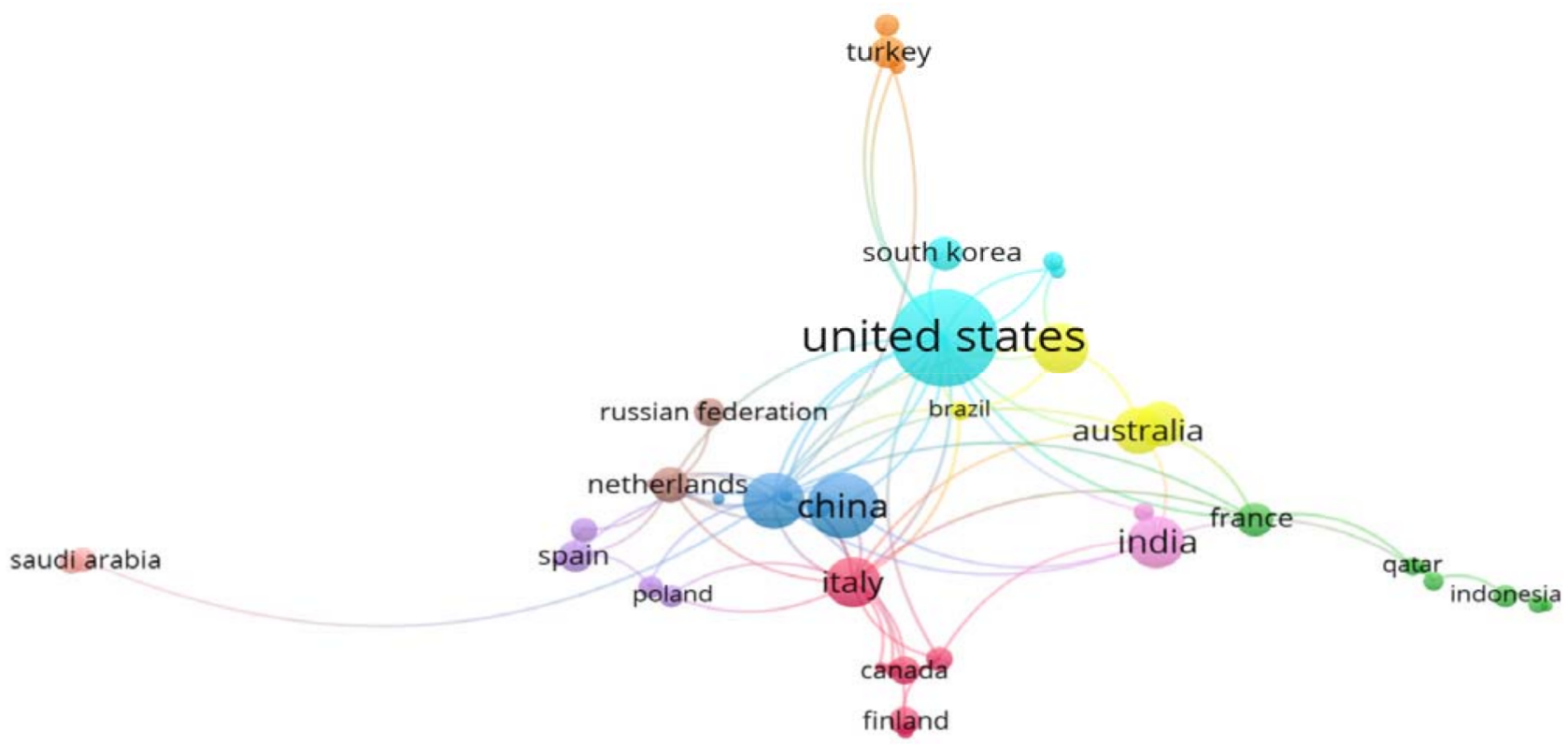

Figure 5. Collaboration network between countries and territories on the subject. Source: VOSviewer (2020).

The cluster colors display ten identifiable main groups. The first group relates to the United States and South Korea. They were followed by China and the United Kingdom (second group). The third comprises Germany, Brazil, and Australia. The fourth adds Russia and Netherlands. The fifth relates to Canada and Italy. In general, the absence of the countries in the world that are most prone to disasters and less developed countries face significant challenges in terms of governance, poverty, lack of disaster warning systems, infrastructure deficiencies, deficient healthcare systems, and lack of comprehensive disaster management plans.

The group linked to the United States has one Asian contributor, South Korea. The group from the Netherlands has substantial affinities with countries from the same Euro- 
pean continent. Turkey, Iran, and Saudi Arabia are the most distant countries in terms of collaboration between authors.

\subsubsection{Institutions}

Table 5 shows the classification of the 16 most relevant universities and institutions according to the Scopus database. Two hundred forty-eight research institutions participated in 273 publications, all of which have information on the authors' affiliation. Of the total institutions, $94 \%$ had only one publication, $2.8 \%$ had two publications, $2.8 \%$ had three publications, whereas only one institution, $0.4 \%$, had five publications on the subject. Table 5 provides information on the top 16 institutions with the most publications on the topic.

Table 5. Top 16 most productive institutions on the subject. Source: Scopus (2020).

\begin{tabular}{cccc}
\hline No. & Institutions & Country & Number of Publications \\
\hline 1 & Griffith Business School & Australia & 5 \\
2 & Delft University of Technology & Netherlands & 3 \\
3 & Loughborough University & United Kingdom & 3 \\
4 & Massey University & New Zealand & 3 \\
5 & National University of Singapore & Singapore & 3 \\
6 & National Science and Technology Center for Disaster Reduction & Taiwan & 3 \\
7 & Simon Fraser University & Canada & 3 \\
8 & University of Modena and Reggio Emilia & Italy & 3 \\
9 & University of Münster & Germany & 3 \\
10 & Indian Institute of Technology Roorkee & India & 2 \\
11 & Asian Institute of Technology & Thailand & 2 \\
12 & Chung Shan Medical University & Taiwan & 2 \\
13 & East Carolina University & USA & 2 \\
14 & Graz University of Technology & Austria & 2 \\
15 & Pennsylvania State University & USA & 2 \\
\hline
\end{tabular}

For the top institutions, the most recurrent countries are Australia, the Netherlands, the United Kingdom, Italy, Germany, India, and the United States, which are also among the top 10 with the most significant number of publications on the subject. Griffith Business School from Australia, with five publications, is the institution with the most publications. Most institutions are universities, but there are some research centers, such as the National Science and Technology Center for Disaster Reduction. Of the participating institutions by country, the most significant number of institutions are from the United States, which has 62 institutions that have published works on the subject, equivalent to about $25 \%$ of total institutions. The U.S. is followed by China ( $8 \%)$, India (7\%), Germany $(6 \%)$, and Italy $(5 \%)$. Of the total institutions, over $50 \%$ are universities, $15 \%$ are institutions, and $7 \%$ are research centers, such as the European Research Center for Information Systems (ERCIS), National Science and Technology Center for Disaster Reduction, and Stanley Ho Big Data Decision Analytics Research Centre.

Griffith Business School is Australia's most important public university that commercializes research services for companies, industries, and governments through Griffith Enterprise. Advanced Design and Prototyping Technologies (ADaPT) is a research institute that collaborates with industries to expand the limits of advanced personalized design, the quick creation of prototypes and new materials, and the next industrial revolution or Industry 4.0 and Supply Chain 4.0. This approach generates the most productive university in the development of supply chain technologies.

On the other hand, Delft University of Technology is one of the most prestigious universities in Europe and the world. According to the Times Higher Education, it is rated as the best university in the European Union and ranked 15th place worldwide in engineering and information technologies for humanitarian logistics. 


\subsection{Analysis of Citations}

The analysis of citations indicates the number of times the publications on the subject have been cited in other publications in the Scopus database. In total, the 342 publications were cited 4839 times in other publications. A total of $32.7 \%$ of articles have not been cited; $12.3 \%$ have been cited once; $36 \%$ of the publications have between 2 and 10 citations, and $19 \%$ have more than ten citations. Currently, researchers have found that citations are highly related to visibility, which implies that publications with free access tend to be cited more often [38]. Table 6 lists the ten most-cited publications.

The study by Richards [39], "Space Technology Contributions to Emergency and Disaster Management," is the oldest article on the subject and was published in 1983. The article with the most annual citations is "Automated Planning: Theory and Practice" by Ghallab M., Nau D., and Traverso P., (2004) [40] from the institute LAAS-CNRS, Toulouse (France). Since its publication in 2004, it has been cited 94 times a year. It is followed by the article by Caunhye A.M., Nie X., and Pokharel S. (2012), "Optimization models in emergency logistics: A literature review" [41] from Nanyang Technological University (Japan). Since its publication in 2012, it has had 56 citations per year. In the list of most cited publications, the United States is the most frequent country of origin of the first author, with a frequency of three, followed by Turkey with a frequency of two. Based on the central subject of the publications, eight of the articles cover topics on humanitarian logistics, disaster assistance, and placement and location.

The journals with the most citations are "Socio-economic Planning Sciences," with $10 \%$ of total citations on the subject, followed by the Journal of Humanitarian Logistics and Supply Chain Management, Supply Chain Management, European Journal of Operational Research, Interfaces, Proceedings-IEEE Military Communications Conference MILCOM, which account for $20 \%$ of total citations. Of the top 10 published articles, the oldest was published in 2003 and has 80 cites, followed by the most cited article, which has been cited 1502 times since 2004. In contrast, the most recent article, from 2015, has 180 citations. All the top publications have been written in the last 17 years. The most cited article is 16 years old, followed by an 8-year-old article.

\subsection{Analysis of Co-Citations}

In this analysis of citations, we identify the number of references used by the 342 articles on the subject, to which end 8799 references were analyzed, equivalent to an average of 26 references per article. Figure 6 displays the networks of co-citations, while at the same time quantifying the relationships or links between the publications. In the 342 articles, 1035 authors were found, and it was decided to include those who appear more than twice in the network. Of the 8799 references, 1763 passed this threshold. In the network, the size of the circle represents a more significant number of citations in the publications about technologies in the humanitarian supply chain. The distance represents the closeness of relationships between two publications and their level of similarity. When publications are shaded in the same color, their subject has a high level of affinity. In the network, seven groups can be identified. 
Table 6. Top 10 publications with most citations on the subject. Source: Scopus (2020).

\begin{tabular}{|c|c|c|c|c|c|c|c|c|}
\hline No & Publication Title & Author(s) & $\begin{array}{c}\text { Country of First } \\
\text { Author }\end{array}$ & Institution & $\begin{array}{c}\text { Journal-SJR } \\
\text { (2019)-SNIP (2019) }\end{array}$ & Times Cited & $\begin{array}{c}\text { Average Citations } \\
\text { Per Year }\end{array}$ & Main Topic \\
\hline 1 & $\begin{array}{c}\text { Automated Planning: Theory } \\
\text { and Practice }\end{array}$ & $\begin{array}{l}\text { Ghallab M., Nau D., } \\
\text { Traverso P. (2004) [40] }\end{array}$ & France & $\begin{array}{l}\text { Instituto } \\
\text { LAAS-CNRS, } \\
\text { Toulouse }\end{array}$ & Book & 1502 & 94 & $\begin{array}{c}\text { Task planning (robotics), } \\
\text { technological planning for } \\
\text { emergencies }\end{array}$ \\
\hline 2 & $\begin{array}{l}\text { Optimization Models in Emergency } \\
\text { Logistics: A Literature Review }\end{array}$ & $\begin{array}{l}\text { Caunhye A.M., Nie X., } \\
\text { Pokharel S. (2012) [41] }\end{array}$ & Japan & $\begin{array}{l}\text { Nanyang } \\
\text { Technological } \\
\text { University }\end{array}$ & $\begin{array}{c}\text { Socioeconomic } \\
\text { planning Sciences } \\
(1.318-2.218) \\
\end{array}$ & 445 & 56 & $\begin{array}{c}\text { Humanitarian logistics, } \\
\text { disaster relief, } \\
\text { location-assignment }\end{array}$ \\
\hline 3 & $\begin{array}{l}\text { Pre-positioning of Emergency Items } \\
\text { for CARE International }\end{array}$ & $\begin{array}{l}\text { Duran S., Gutiérrez M.A., } \\
\text { Keskinocak P. (2011) [42] }\end{array}$ & Turkey & $\begin{array}{l}\text { Middle East } \\
\text { Technical } \\
\text { University }\end{array}$ & $\begin{array}{c}\text { Interfaces } \\
(0.609-0.619)\end{array}$ & 186 & 21 & $\begin{array}{l}\text { Humanitarian logistics, } \\
\text { disaster relief, } \\
\text { location-assignment }\end{array}$ \\
\hline 4 & $\begin{array}{c}\text { Models, Solutions, and Enabling } \\
\text { Technologies in } \\
\text { Humanitarian Logistics }\end{array}$ & $\begin{array}{l}\text { Özdamar L., } \\
\text { Ertem M.A. (2015) [43] }\end{array}$ & Turkey & $\begin{array}{l}\text { Yeditepe } \\
\text { University }\end{array}$ & $\begin{array}{c}\text { European Journal of } \\
\text { Operations Research } \\
(0.618-0.715)\end{array}$ & 180 & 36 & $\begin{array}{c}\text { Humanitarian logistics, } \\
\text { disaster relief, } \\
\text { location-assignment }\end{array}$ \\
\hline 5 & $\begin{array}{l}\text { Developing Supply Chains in } \\
\text { Disaster Relief Operations through } \\
\text { Cross-sector Socially Oriented } \\
\text { Collaborations: A Theoretical Model }\end{array}$ & $\begin{array}{l}\text { Maon F., Lindgreen A., } \\
\text { Vanhamme J. (2009) [44] }\end{array}$ & Belgium & $\begin{array}{l}\text { Université } \\
\text { Catholique de } \\
\text { Louvain }\end{array}$ & $\begin{array}{l}\text { Supply Chain } \\
\text { Management } \\
(1.676-2.158)\end{array}$ & 125 & 11 & $\begin{array}{l}\text { humanitarian logistics, } \\
\text { disaster relief, } \\
\text { location-assignment }\end{array}$ \\
\hline 6 & $\begin{array}{l}\text { A Decade of Supply Chain } \\
\text { Collaboration and Directions for } \\
\text { Future Research }\end{array}$ & $\begin{array}{l}\text { Soosay C.A., Hyland P. } \\
\text { (2015) [45] }\end{array}$ & Australia & $\begin{array}{l}\text { University of South } \\
\text { Australia Business } \\
\text { School }\end{array}$ & $\begin{array}{l}\text { Supply Chain } \\
\text { Management } \\
(1.676-2.158)\end{array}$ & 106 & 21 & $\begin{array}{l}\text { Collaboration in the supply } \\
\text { chain, transportation } \\
\text { management; vendor } \\
\text { managed inventory }\end{array}$ \\
\hline 7 & $\begin{array}{l}\text { Speech-gesture Driven Multimodal } \\
\text { Interfaces for Crisis Management }\end{array}$ & $\begin{array}{l}\text { Sharma R., Yeasin M., } \\
\text { Krahnstoever N., } \\
\text { Rauschert I., Cai G., Brewer } \\
\text { I., MacEachren A.M., } \\
\text { Sengupta K. (2003) [11] }\end{array}$ & USA & State College & $\begin{array}{l}\text { Proceedings of the } \\
\text { IEEE (2.329-5.334) }\end{array}$ & 80 & 5 & $\begin{array}{l}\text { Multimodal interaction, } \\
\text { natural language interfaces, } \\
\text { public speaking }\end{array}$ \\
\hline 8 & $\begin{array}{l}\text { Designing Gaming Simulations for } \\
\text { the Assessment of Group Decision } \\
\text { Support Systems in } \\
\text { Emergency Response }\end{array}$ & $\begin{array}{l}\text { Mendonça D., Beroggi } \\
\text { G.E.G., van Gent D..' } \\
\text { Wallace W.A. (2006) [46] }\end{array}$ & USA & $\begin{array}{l}\text { Instituto de } \\
\text { Tecnología de } \\
\text { Nueva Jersey }\end{array}$ & $\begin{array}{l}\text { Safety Science } \\
(1.241-2.589)\end{array}$ & 65 & 5 & $\begin{array}{l}\text { Crisis management, fire } \\
\text { service, commanders }\end{array}$ \\
\hline 9 & $\begin{array}{c}\text { Improving Humanitarian } \\
\text { Operations through } \\
\text { Technology-enabled Collaboration }\end{array}$ & $\begin{array}{l}\text { Ergun O., Gui L., Heier } \\
\text { Stamm J.L., Keskinocak P., } \\
\text { Swann J. (2014) [47] }\end{array}$ & USA & $\begin{array}{l}\text { Georgia Institute of } \\
\text { Technology }\end{array}$ & $\begin{array}{l}\text { Producción y } \\
\text { Gestión de } \\
\text { Operaciones } \\
(2.843-1.950)\end{array}$ & 57 & 10 & $\begin{array}{l}\text { Humanitarian logistics, } \\
\text { disaster relief, } \\
\text { location-assignment }\end{array}$ \\
\hline 10 & $\begin{array}{l}\text { Hybrid Zigbee RFID Sensor Network } \\
\text { for Humanitarian Logistics } \\
\text { Center Management }\end{array}$ & $\begin{array}{l}\text { Yang H., Yang L., Yang } \\
\text { S.-H. (2011) [48] }\end{array}$ & $\begin{array}{l}\text { United } \\
\text { Kingdom }\end{array}$ & $\begin{array}{l}\text { Loughborough } \\
\text { University }\end{array}$ & $\begin{array}{l}\text { Journal of Network } \\
\text { and Computer } \\
\text { Applications } \\
(1.389-3.154)\end{array}$ & 55 & 6 & $\begin{array}{c}\text { Humanitarian logistics, } \\
\text { disaster relief, } \\
\text { location-assignment }\end{array}$ \\
\hline
\end{tabular}




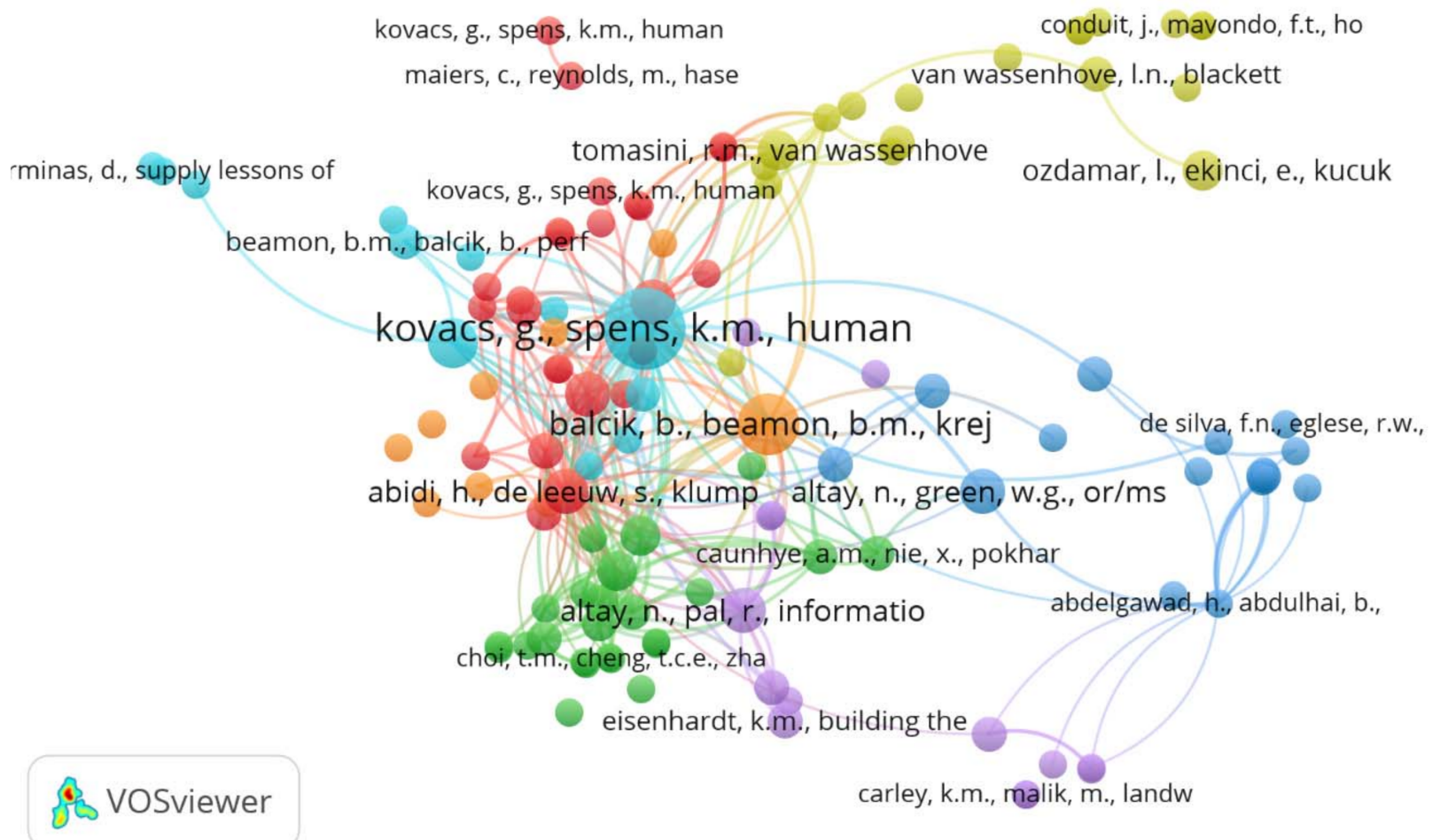

Figure 6. Analysis of most frequent co-citations on the subject. Source: Scopus (2020).

The blue (light) and red groups display more significant interaction with the others, while the yellow group is distant. The blue (light) cluster may be more closely related to its central author, Kovacs, G. Around the red cluster; there are topics related to information technology studies, flexibility, speed, and adaptability in humanitarian supply chain operations, as well as the assessment of the position of information technology and emergency management. The red cluster is more closely related to the authors Kabra, G., and Ramesh, A., who are the authors with the most significant number of publications on the subject. The yellow cluster highlights the models, solutions, and technologies available for the subject, headed by Ordenar, I. and Eterm, M.A. The purple and orange clusters have an affinity with topics related to technology in the coordination of emergency operations in rescue chains. Duba, R., Luo, Z., Gunasekaran, A., Akter, s., Hazen, B.T., and Douglas, M.A. of the orange cluster propose using big data analysis for predictions in the humanitarian logistics chain. The list of the most frequently co-cited articles includes: "Humanitarian Logistics in Disaster Relief Operations" (2007) [49], "Coordination in Humanitarian Relief Chains: Practices, Challenges and Opportunities" (2010) [50], "Humanitarian Supply Chain Performance Management: A Systematic Literature Review" (2014) [51], and "Identifying Challenges in Humanitarian Logistics" (2009) [52]. These publications have 171, 105, 88, and 76 citations, respectively.

\subsection{Analysis of Subject Categories}

In Scopus, an analysis was carried out to identify the most common categories of research in the humanitarian supply chain. They can be divided into four main categories, which are described in Figure 7. The engineering category has the most significant number of research studies on this subject in the Scopus database, with $33.5 \%$ of total publications, followed by computer science with $26.9 \%$. It should be noted that one publication may be listed under more than one category. 


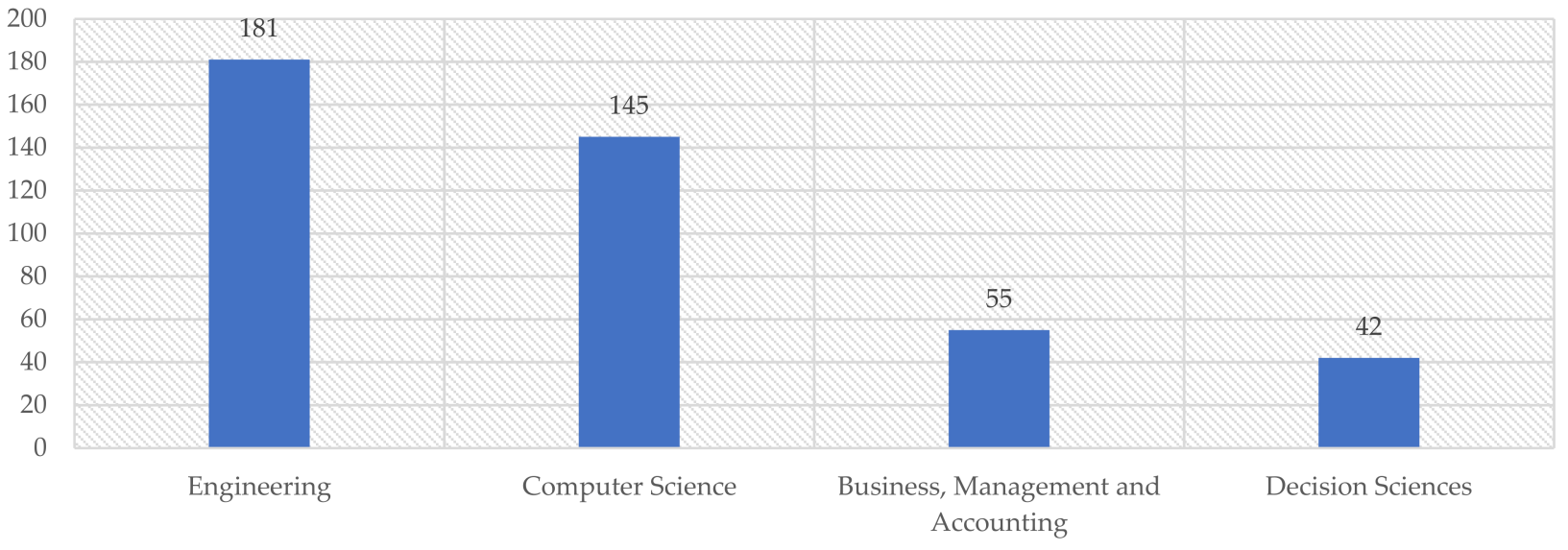

Figure 7. The most frequent sub-topics of the publications in the database. Source: Scopus (2020).

Technological progress and the growth of society have produced competitive advantages for the areas of engineering and computer science due to the multi-functionality of their contents, which enables them to interact with any environment and to contribute to understanding problems through the identification of root causes (engineering) and technological solutions (computer science), as a result of which there is a high level of correlation between these sub-topics in the subject of this bibliometric study.

\subsection{Analysis of Terms}

The analysis of the terms used in the titles and abstracts of the articles helps identify trends in new research on the subject (see Figure 8). This analysis was carried out using the VOSviewer software to visualize the network of terms. The analysis covered 342 articles and included only terms that appear at least in five publications. Two hundred thirtyone terms were included in the network, which is displayed in Figure 8. In the chart generated by the software, the circles symbolize the relevance of the terms, and the distance between them represents the relationships between them (a closer distance represents a more vital link). The connection between terms is based on the number of times they appear simultaneously in the title and abstract. As a result, nine colors are assigned to the clusters. Figure 8 highlights the most frequently used keywords in the publications. The three most frequent terms are Disaster, Humanitarian Logistics, Human. This situation shows the importance of logistics in the context of the humanitarian supply chain. Logistics account for around $80 \%$ of disaster relief operations [53]. All the keywords included in the top three positions illustrate the challenges currently faced by humanitarian organizations. They are expected to secure financing from donors, but they must also develop technological models, frameworks, and strategies to optimize their operations and resources to reach all those in need in several disaster sites worldwide.

The red cluster lists the most significant number of terms; these terms are closely related to strategic aspects in which humans are considered an essential objective when formulating the emergency humanitarian assistance plan (human(s), aged, human experiment, procedures, methodology, diagnosis, case report, risk factor, retrospective studies, education). The yellow group includes terms associated with technological tools in emergencies (artificial intelligence, big data, virtual reality, block-chain, user interfaces, human-computer interaction, information system, computer simulation model, remote sensing, internet of things). The blue cluster (top) lists the terms related to communication systems (communication, telecommunication, smartphones, wireless communications, wireless telecommunication systems, signal processing, global positioning systems, digital storage, automatization). The brown cluster lists organizations that manage and implement emergency response plans (civil defense, European Commission, civil protection). The green cluster covers the terms associated with the emergency assistance in the supply chain management (disaster management, inventory management, logistics, supply chain, 
humanitarian operations, information technology, humanitarian aid, humanitarian supply chain management, supply chain management). Other frequent terms are names of countries (United States, Taiwan, Japan) and terms related to the type of emergency, grouped under the blue (bottom) cluster (floods, storm, flooding, natural hazards).

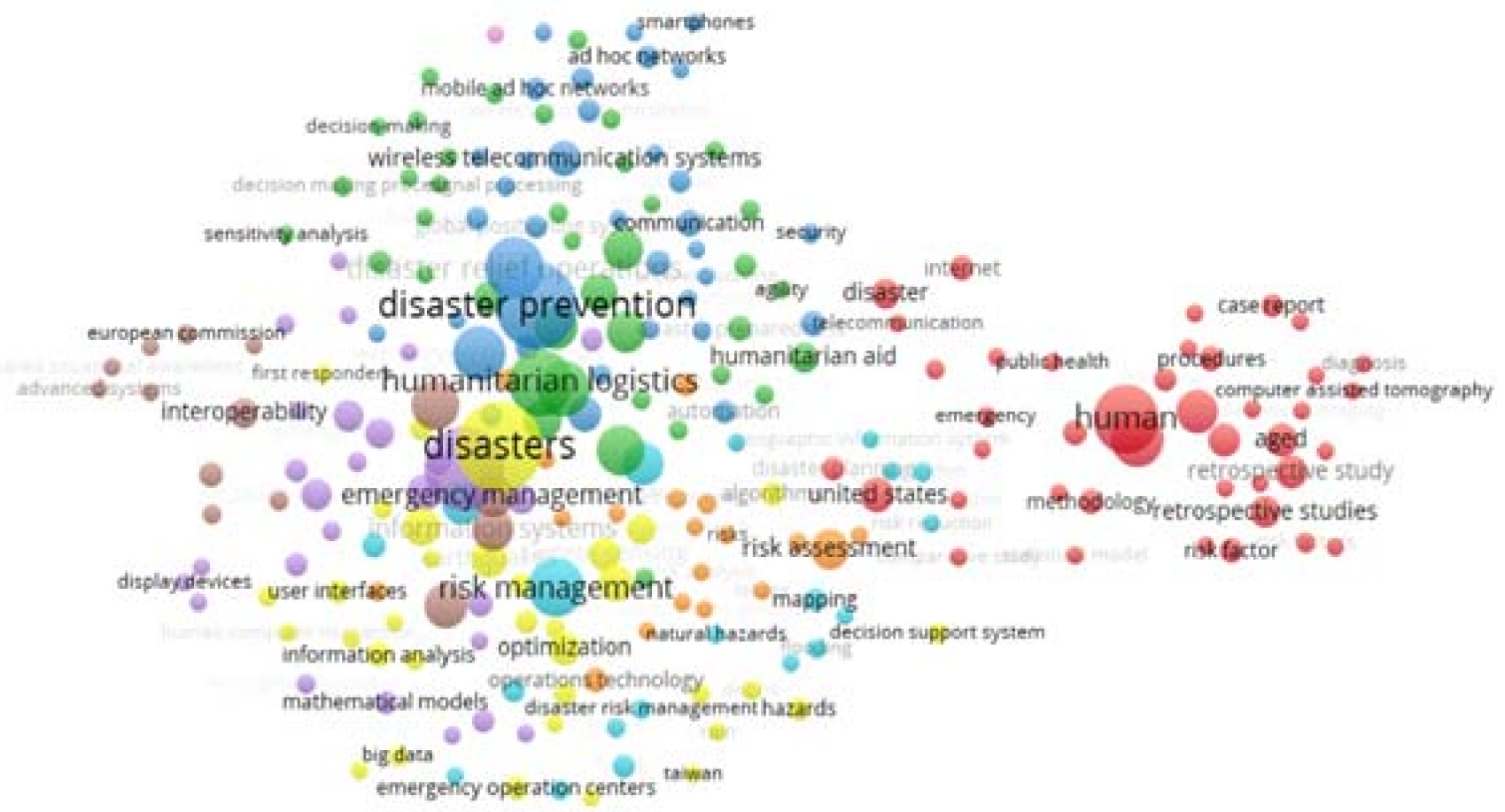

Figure 8. Terms of analysis on the subject. Source: VOSviewer (2020).

Figure 9 displays the terms of analysis over time, enabling the identification of future trends in research on the subject. The color of the terms signifies their average time of publication. This is determined as the average of all the publications containing the term in the title or abstract. The most frequently used terms were in the range from 2012 to 2016. The oldest terms tend to be bluer, whereas the newest terms tend to be yellower. Based on the color shades, the most recurrent terms are between 2012 and 2014, representing the trend in using keywords over the years (2010-2018). Concerning the trend, the initial approach towards supply chain technologies focused on communications, risk assessment, resource management, and administration, and since then, the terms have evolved towards technologies associated with Supply Chain 4.0 in the yellow cluster. These topics include organizational entrepreneurship leading culture for open innovation dynamics.

The technological tool cluster is the most contemporary throughout the subject (technology adoption, block-chain, big data, internet of things, information, and communication technology), considering the cost/benefits of their implementation. On the other hand, the cluster related to the emergency response in the supply chain management framework and strategic aspects include terms that tend to be older. Compared to the areas of study (Section 3.7 on sub-topics), this trend may be related to the increase in the number of studies on engineering and computer science regarding technological tools required for research these two areas.

\subsection{Management Implications}

The new information technologies (newIT) are tools that facilitate planning and collaboration between humanitarian logistics entities. In addition, they improve transaction processing, activity monitoring, and control, and they aid delivery coordination. The newIT facilitated a disaster response system in Zimbabwe. These applications guarantee 
the supply of medicines, the availability of products, and essential elements for the care and support of victims [54].

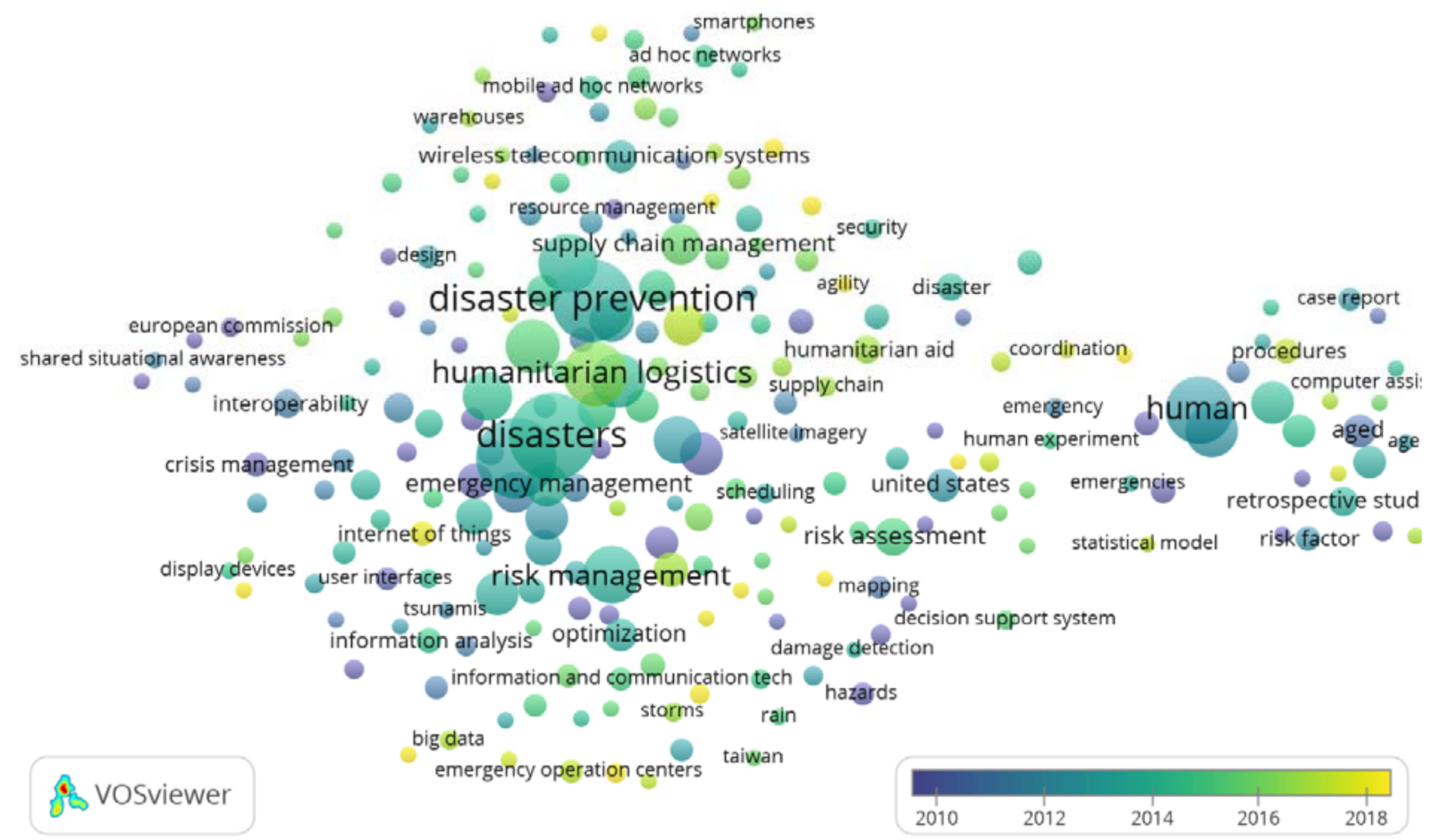

Figure 9. Analysis of representative terms on the subject over time. VOSviewer: Scopus (2020).

Another study developed an integrated logistic information system based on the web and smartphones for disaster response. In this case, government agencies, donors, and stakeholders can manage aid distribution to emergency areas as suddenly as possible [55]. Similarly, mobile cloud computing (MCC) showed the potential to improve communication and information management during emergency operations due to disasters. The key performance factors are the reliability of the connection, security, privacy, and management of the victims' data [56]. Mobile technology improved the performance of humanitarian logistics by managing reliable information for delivering aid to refugees in sub-Saharan Africa, the refugee camps of Jordan, and Germany [57].

The research examined the technology adoption behavior of humanitarian organizations [27]. The modeling results show that performance expectation and effort expectation significantly affect the adoption of newIT. This situation generates the need to consolidate a learning culture with efforts to improve education and skills in IT and data mining as an integral part of its activities. The above shows that the use of newIT to support humanitarian logistics is a developing research area.

Humanitarian logistics must take advantage of the benefits offered by the advancement of big data analysis due to the amount of unstructured data generated during a disaster in a short time [10]. China's Emergency Operations Center (EOC) developed a knowledge management system (KMS) based on large volumes of data to support decisionmaking processes [58]. The proposed system was intended to improve awareness and regulate human behaviors regarding emergencies.

On the other hand, applications of sensor networks, the Internet of Things (IoT), and smartphones for data capture will increase big data analysis [59]. These applications would reduce the impacts associated with disasters and improve the design of mitigation strategies (for example, the weather forecast and rainfall monitoring in real-time). Furthermore, disasters often cause the collapse of the information and communication technology (ICT) infrastructure, hampering the agility of humanitarian logistics. Therefore, big data satellite 
analysis on real-time weather information, such as geospatial data on a cloud computing platform can help better coordination and collaboration between rescue teams [60].

A Humanitarian Logistics Digital Business Ecosystem (HLDBE) was developed as a strategy to sustain operations and support through a hybrid humanitarian-business logistics system [61]. This strategy consolidates financial reserves and builds capacities to benefit stakeholders. Therefore, newIT and emerging technologies are critical factors for the digital transformation of humanitarian logistics.

Other emerging technologies used in humanitarian logistics include blockchain-based smart contracts, virtual reality, and 3D printing, among others. Blockchain technology can improve rescue operations' transparency, guarantee an allocation of resources to victims, reduce transaction costs, and monitor supply chain operations [62]. Some researchers have recruited volunteers to carry out disaster relief operations and to deal with physical and mental problems. They use digital media in the logistics operation for the learning and awareness of the interested parties [63].

Some technologies such as artificial intelligence, blockchain, and 3D printing can reduce uncertainty related to information updating, budget execution, resource management, and efficiency of rescue operations in a humanitarian supply chain [64]. Moreover, a study proposed integrating multi-objective optimization algorithms, GIS, and emerging artificial intelligence technologies. This approach could solve multi-objective geospatial optimization problems in the future logistics management of urban emergencies [65].

Emerging technologies such as the Internet of Things (IoT), 3D/4D printing, AR/MR/VR, cyber-physical systems (CPS), robotics, new human-machine interfaces (HMI), artificial intelligence (AI), big data techniques, machine learning (ML), deep learning (DL), 5G/6G connectivity, and new computing paradigms, when oriented towards the Sustainable Development Goals (SDGs), will bring a wide range of disruptive solutions in multiple fields [66].

Finally, the agility of humanitarian relief operations can be increased by using big data analytics to improve the accuracy of the information, the planning of rescue operations, the performance of remote sensing monitoring, and information security [10,60]. In addition, operations in a humanitarian supply chain require information intelligence, big data analysis, knowledge of social vulnerabilities, and stakeholders [59].

\section{Conclusions}

The main objective of this study is to provide an overall view of the development of technologies in the humanitarian supply chain. A bibliometric analysis was performed to identify the contributions and interrelationships between technologies and the "Humanitarian Supply Chain" extracted from the Scopus database to achieve this objective. This analysis is based on a sample of 342 articles, which enabled the identification of global research trends on this subject from 1983 to 2020 and forecasting (using MS Excel) the number of articles expected by 2025. Research on this subject has displayed a growing trend, with a considerable increase in the last eight years, particularly in 2019, with the most significant number of publications. The leading science areas are engineering, understanding the causes and solutions for the problem; computer science; designing, developing, and implementing technological solutions; business to assess the costs and benefits of the investment. Engineering was found to be a central area of study. The Journal of Humanitarian Logistics and Supply Chain Management is considered the most closely focused journal on the subject. The most important institution in terms of contributions to the field by the number of documents is the Griffith Business School. In terms of total citations, the leading institution is LAAS-CNRS, Toulouse. In geographic terms, the most productive countries are the United States (in terms of the number of documents) and France (by citations).

The following are some of the most critical aspects of the bibliometric review.

The number of publications on the subject is directly correlated with the tsunami in the Indian Ocean (2004), Hurricane Katrina (2005), the earthquake in Haiti (2010), and the 
tsunami in Japan (2011). In these specific years, the number of publications increased. An increase in the number of publications is expected starting in 2020 due to the current health emergency caused by the COVID-19 virus, which has challenged the entire humanitarian supply chain's effectiveness in supplying essential products, protection equipment, and healthcare materials not locally available.

A select group of authors (1\%) made many contributions to publications related to the humanitarian supply chain. Ramesh and Kabra, the most productive authors, are from the same country and are affiliated with the Roorkee Institute of Technology in India. Both authors' research focuses on humanitarian logistics, disaster relief, placement, and assignment. They show a high level of collaboration in the research subject of their interest, including humanitarian logistics, placement and assignment, supply chain management, and $3 \mathrm{D}$ printing.

Of the total journals on the subject, $97 \%$ have produced only one or two publications.

- The Journal of Humanitarian Logistics and Supply Chain Management is a magazine created to publish articles related to "all aspects of humanitarian logistics and supply chain management," making it the most crucial journal on this subject. It recently was awarded (in 2020) the "Emerald Literati Awards" for its contribution to scientific knowledge on topics related to the humanitarian supply chain.

- The United States is the most productive country, but none of its authors are in the top five of the most productive authors. The United States, China, and India are among the top 20 most innovative countries in the world, according to the "2019 Global Innovation Index" of the Work Intellectual Property Organization. Additionally, an absence of publications on the subject was observed in the world's most disaster-prone and least developed countries.

- $\quad$ A high proportion of the publications (33\%) have not been cited by others, whereas a small number of publications (4\%) have been cited more than 50 times.

- Engineering and computer science are the areas in which most research has been carried out in connection with this subject, with $33.5 \%$ and $26.9 \%$ of the total, respectively. The keywords associated with these areas include technology adoption, block-chain, big data, the Internet of Things, information, and communication technology, which are also the newest terms associated with expected future studies on the humanitarian supply chain.

- Caunhye, Nie, and Pokharel [41] developed the most cited article that presents a literature review related to optimization models in emergency logistics, including disaster operations such as evacuation, facility location, and transportation.

- The leading universities in terms of production on this subject are Griffith Business School (Australia), Delft University of Technology (Netherlands), and Loughborough University (United Kingdom). Griffith has its research institute (ADaPT), which focuses on quickly developing prototypes, new materials, and advanced personalized design associated with Industry 4.0 and Supply Chain 4.0.

- This bibliometric study shows a wide range of trends or concentrations of terms over time, scientific areas, research centers, journals, countries, and topics. These results could facilitate the planning, design, and publishing of future research on humanitarian supply chain technologies.

Some of the most important research studies include that by Rodríguez-Espíndola, Chowdhury, Beltagui, and Albores [64], who presented solutions based on disruptive technologies for the floods in Tabasco, Mexico to shorten delivery times, increasing the transparency, traceability, and accountability of the material and financial resources. In turn, Dubey, Gunasekaran, Bryde, Dwivedi, and Papadopoulos [62] proposed a theoretical model to understand how Blockchain can quickly influence transparency and trust in disaster relief in supply chain operations. Nagendra, Narayanamurthy, and Moser [60] proposed developing a big data analytics platform that was developed based on meteorological data in real-time and geo-spatial data to improve coordination and collaboration between humanitarian disaster relief teams in the case of floods in Kerala (India) in 2018. These 
solutions included technologies and knowledge to generate open innovation into the supply chain. Some technologies such as blockchain, big data, the Internet of Things, information, and communication technology generate dynamics capabilities to attend the global market and improve organizations' productivity [67].

Four lines of future research are proposed, (1) development and implementation of emerging technologies for disaster relief. Considering the significant contributions of leading-edge technologies such as block-chain [68], big data [62,69], artificial intelligence [70,71], 3D printing, information security, and drones/robots [72], increasing the number of studies on these technologies applied to humanitarian logistics would be a significant contribution. (2) Explore the key challenges and benefits of integrating data from social media (Twitter, Facebook, Instagram) in local-level information systems in affected regions to improve decision-making and response times to the emergency. (3) The use of robots and drones to perform visual assessments of the regions affected by a disaster and facilitate the delivery of assistance and search and rescue missions. (4) Research on slow-occurrence and human-made disasters (wars, forced displacement, terrorism) and health emergencies (the most recent of which is COVID-19). From the perspective of situation factors, the study of the environmental outlook is also a field of study that is notoriously lagging.

This study also indicates that developed countries (United States, China, Japan, Germany) have the most relevant research on this subject published in the Scopus database. The most disaster-prone regions and less developed countries should also appear on this list. Future studies should broaden the reach of this study and improve its findings by incorporating additional sources, including other well-known databases such as Business Source Premier, Science Citation Index, Social Science Citation, and WoS.

Some limitations of this research are presented. First, this study included the results obtained from a literature search on Scopus Database. A comparison between the results of the different databases would be less exclusive. Second, the current health emergency produced by COVID-19 has generated much research related to the humanitarian supply chain, and it could increase the number of publications on the subject in the last few months. Future research may continue to examine the effect of the COVID-19 pandemic into research areas.

Author Contributions: The authors contributed equally to all items of this research. All authors have read and agreed to the published version of the manuscript.

Funding: This research received no external funding.

Institutional Review Board Statement: Not applicable.

Informed Consent Statement: Not applicable.

Data Availability Statement: Data available upon request.

Conflicts of Interest: The authors declare no conflict of interest.

\section{References}

1. Tague-Sutcliffe, J. An introduction to informetrics. Inf. Process. Manag. 1992, 28, 1-3. [CrossRef]

2. Ospina-Mateus, H.; Quintana, L.; Lopez-Valdes, F.J.; Salas-Navarro, K. Bibliometric analysis in motorcycle accident research: A global overview. Scientometrics 2019, 121, 793-815. [CrossRef]

3. Wagner, C.S.; Roessner, J.D.; Bobb, K.; Klein, J.T.; Boyack, K.W.; Keyton, J.; Rafols, I.; Börner, K. Approaches to understanding and measuring interdisciplinary scientific research (IDR): A review of the literature. J. Informetr. 2011, 5, 14-26. [CrossRef]

4. Hannah, R.; Max, R. Natural Disasters. Available online: https://ourworldindata.org/natural-disasters (accessed on 18 December 2020).

5. Dubey, R.; Altay, N.; Blome, C. Swift trust and commitment: The missing links for humanitarian supply chain coordination? Ann Oper. Res. 2019, 283, 159-177. [CrossRef]

6. Abidi, H.; de Leeuw, S.; Klumpp, M. Measuring success in humanitarian supply chains. Int. J. Bus. Manag. Invent. 2013, 2, 31-39.

7. Leiras, A.; de Brito, I., Jr.; Peres, Q.; Bertazzo, R.; Yoshizaki, Y. Literature review of humanitarian logistics research: Trends and challenges. J. Humanit. Logist. Supply Chain Manag. 2014, 4, 95-130. [CrossRef] 
8. Betts, A.; Bloom, L. Humanitarian Innovation: The State of the Art; United Nations Office for the Coordination of Humanitarian Affairs (OCHA): New York, NY, USA, 2014.

9. Kruse, D.J.; Goeldner, M.; Eling, K.; Herstatt, C. Looking for a Needle in a Haystack: How to Search for Bottom-up Social Innovations that Solve Complex Humanitarian Problems. J. Prod. Innov. Manag. 2019, 36, 671-694. [CrossRef]

10. Gupta, S.; Altay, N.; Luo, Z. Big data in humanitarian supply chain management: A review and further research directions. Ann. Oper. Res. 2019, 283, 1153-1173. [CrossRef]

11. Sharma, R.; Yeasin, M.; Krahnstoever, N.; Rauschert, I.; Cai, G.; Brewer, I.; MacEachren, A.M.; Sengupta, K. Speech-gesture driven multimodal interfaces for crisis management. Proc. IEEE 2003, 91, 1327-1354. [CrossRef]

12. Gill, G.S. When all else fails: Amateur radio becomes lifeline of communications during a disaster. Int. J. Emerg. Serv. 2019, 9, 109-121. [CrossRef]

13. Yun, J.J.; Kim, D.; Yan, M.-R. Open innovation engineering-Preliminary study on new entrance of technology to market. Electronics 2020, 9, 791. [CrossRef]

14. Melo, P.N.; Martins, A.; Pereira, M. The Relationship between Leadership and Accountability: A Review and Synthesis of the Research. J. Entrep. Educ. 2020, 23. Available online: http:/ / hdl.handle.net/11328/3251 (accessed on 16 November 2021).

15. Zhu, W.; Wang, Z. The collaborative networks and thematic trends of research on purchasing and supply management for environmental sustainability: A bibliometric review. Sustainability 2018, 10, 1510. [CrossRef]

16. Reyes, J.; Solano-Charris, E.; Montoya-Torres, J. The storage location assignment problem: A literature review. Int. J. Ind. Eng. Comput. 2019, 10, 199-224. [CrossRef]

17. Meza-Peralta, K.; Gonzalez-Feliu, J.; Montoya-Torres, J.R.; Khodadad-Saryazdi, A. A unified typology of urban logistics spaces as interfaces for freight transport: A Systematic Literature Review. In Supply Chain Forum: An International Journal; Taylor \& Francis: Oxfordshire, UK, 2020; pp. 274-289.

18. Aria, M.; Cuccurullo, C. bibliometrix: An R-tool for comprehensive science mapping analysis. J. Informetr. 2017, 11, 959-975. [CrossRef]

19. Centobelli, P.; Cerchione, R.; Esposito, E.; Oropallo, E. Surfing blockchain wave, or drowning? Shaping the future of distributed ledgers and decentralized technologies. Technol. Forecast. Soc. Chang. 2021, 165, 120463. [CrossRef]

20. Van Nunen, K.; Li, J.; Reniers, G.; Ponnet, K. Bibliometric analysis of safety culture research. Saf. Sci. 2018, 108, 248-258. [CrossRef]

21. Liu, X.; Zhan, F.B.; Hong, S.; Niu, B.; Liu, Y. A bibliometric study of earthquake research: 1900-2010. Scientometrics 2012, 92, 747-765. [CrossRef]

22. Noyons, E.C.; Moed, H.F.; Luwel, M. Combining mapping and citation analysis for evaluative bibliometric purposes: A bibliometric study. J. Am. Soc. Inf. Sci. 1999, 50, 115-131. [CrossRef]

23. Zemigala, M. Tendencies in research on sustainable development in management sciences. J. Clean. Prod. 2019, 218, 796-809. [CrossRef]

24. Bensalem, A.; Kin, V. A bibliometric analysis of reverse logistics from 1992 to 2017. Supply Chain Forum Int. J. 2019, 20, 15-28. [CrossRef]

25. Small, H. Visualizing science by citation mapping. J. Am. Soc. Inf. Sci. 1999, 50, 799-813. [CrossRef]

26. Wang, B.; Pan, S.-Y.; Ke, R.-Y.; Wang, K.; Wei, Y.-M. An overview of climate change vulnerability: A bibliometric analysis based on Web of Science database. Nat. Hazards 2014, 74, 1649-1666. [CrossRef]

27. Kabra, G.; Ramesh, A.; Akhtar, P.; Dash, M.K. Understanding behavioural intention to use information technology: Insights from humanitarian practitioners. Telemat. Inform. 2017, 34, 1250-1261. [CrossRef]

28. Kabra, G.; Ramesh, A. An empirical investigation of the enablers in humanitarian supply chain management in India: A case study. J. Adv. Manag. Res. 2015, 12, 30-42. [CrossRef]

29. Kabra, G.; Ramesh, A. Information technology, mutual trust, flexibility, agility, adaptability: Understanding their linkages and impact on humanitarian supply chain management performance. Risk Hazards Crisis Public Policy 2016, 7, 79-103. [CrossRef]

30. Kabra, G.; Ramesh, A. Exploring the challenges in implementation of information technology in humanitarian relief organisations in India: A qualitative study. In Managing Humanitarian Logistics; Springer: Berlin/Heidelberg, Germany, 2016; pp. 105-113.

31. Kabra, G.; Ramesh, A. An analysis of the interactions among the enablers of information communication technology in humanitarian supply chain management: A fuzzy-based relationship modelling approach. In Handbook of Research on Intelligent Techniques and Modeling Applications in Marketing Analytics; IGI Global: Hershey, PA, USA, 2017; pp. 62-73.

32. Tatham, P.; Ball, C.M.; Wu, Y.; Diplas, P. Using long endurance remotely piloted aircraft systems to support humanitarian logistic operations: A case study of cyclone winston. In Smart Technologies for Emergency Response and Disaster Management; IGI Global: Hershey, PA, USA, 2018; pp. 264-278.

33. Tatham, P.; Neal, C.; Wu, Y. Hybrid cargo airships: A humanitarian logistic game changer? J. Humanit. Logist. Supply Chain Manag. 2017, 7, 102-125. [CrossRef]

34. Tatham, P.; Ball, C.; Wu, Y.; Diplas, P. Long-endurance remotely piloted aircraft systems (LE-RPAS) support for humanitarian logistic operations: The current position and the proposed way ahead. J. Humanit. Logist. Supply Chain Manag. 2017, 7, 2-25. [CrossRef]

35. Tatham, P.; Loy, J.; Peretti, U. Three dimensional printing-A key tool for the humanitarian logistician? J. Humanit. Logist. Supply Chain Manag. 2015, 5, 188-208. [CrossRef] 
36. Tatham, P.; Stadler, F.; Murray, A.; Shaban, R.Z. Flying maggots: A smart logistic solution to an enduring medical challenge. J. Humanit. Logist. Supply Chain Manag. 2017, 7, 172-193. [CrossRef]

37. WIPo. Global Innovation Index (GII). Available online: https://www.wipo.int/global_innovation_index/es/2019/\#: \{\}:text= de $\% 20$ redes $\% 20$ sociales,Clasificaci\%C3\%B3n, del\%20\%C3\%8Dndice\%20Mundial\%20de\%20Innovaci\%C3\%B3n (accessed on 1 December 2020).

38. Whipple, E.C.; Dixon, B.E.; McGowan, J.J. Linking health information technology to patient safety and quality outcomes: A bibliometric analysis and review. Inform. Health Soc. Care 2013, 38, 1-14. [CrossRef] [PubMed]

39. Richards, P.B. Space technology contributions to emergency and disaster management. Adv. Earth Oriented Appl. Space Techn. 1982, 1, 215-221.

40. Ghallab, M.; Nau, D.; Traverso, P. Automated Planning: Theory and Practice; Elsevier: Amsterdam, The Netherlands, 2004.

41. Caunhye, A.M.; Nie, X.; Pokharel, S. Optimization models in emergency logistics: A literature review. Socio-Econ. Plan. Sci. 2012, 46, 4-13. [CrossRef]

42. Duran, S.; Gutierrez, M.A.; Keskinocak, P. Pre-positioning of emergency items for CARE international. Interfaces 2011, 41, $223-237$. [CrossRef]

43. Özdamar, L.; Ertem, M.A. Models, solutions and enabling technologies in humanitarian logistics. Eur. J. Oper. Res. 2015, 244, 55-65. [CrossRef]

44. Maon, F.; Lindgreen, A.; Vanhamme, J. Developing supply chains in disaster relief operations through cross-sector socially oriented collaborations: A theoretical model. Supply Chain Manag. Int. J. 2009, 14, 149-164. [CrossRef]

45. Soosay, C.A.; Hyland, P. A decade of supply chain collaboration and directions for future research. Supply Chain Manag. Int. J. 2015, 20, 613-630. [CrossRef]

46. Mendonca, D.; Beroggi, G.E.; Van Gent, D.; Wallace, W.A. Designing gaming simulations for the assessment of group decision support systems in emergency response. Saf. Sci. 2006, 44, 523-535. [CrossRef]

47. Ergun, Ö.; Gui, L.; Heier Stamm, J.L.; Keskinocak, P.; Swann, J. Improving humanitarian operations through technology-enabled collaboration. Prod. Oper. Manag. 2014, 23, 1002-1014. [CrossRef]

48. Yang, H.; Yang, L.; Yang, S.-H. Hybrid Zigbee RFID sensor network for humanitarian logistics centre management. J. Netw. Comput. Appl. 2011, 34, 938-948. [CrossRef]

49. Kovács, G.; Spens, K.M. Humanitarian logistics in disaster relief operations. Int. J. Phys. Distrib. Logist. Manag. 2007, 37, 99-114. [CrossRef]

50. Balcik, B.; Beamon, B.M.; Krejci, C.C.; Muramatsu, K.M.; Ramirez, M. Coordination in humanitarian relief chains: Practices, challenges and opportunities. Int. J. Prod. Econ. 2010, 126, 22-34. [CrossRef]

51. Abidi, H.; De Leeuw, S.; Klumpp, M. Humanitarian supply chain performance management: A systematic literature review. Supply Chain Manag. Int. J. 2014, 19, 592-608. [CrossRef]

52. Kovács, G.; Spens, K. Identifying challenges in humanitarian logistics. Int. J. Phys. Distrib. Logist. Manag. 2009, 39, 506-528. [CrossRef]

53. Van Wassenhove, L.N. Humanitarian aid logistics: Supply chain management in high gear. J. Oper. Res. Soc. 2006, 57, 475-489. [CrossRef]

54. Chingono, T.; Mbohwa, C. Information Technologies for Humanitarian logistics and supply Chain Management in Zimbabwe. In Proceedings of the International Conference on Industrial Engineering and Operations Management, Kuala Lumpur, Malaysia, 8-10 March 2016; pp. 1038-1046.

55. Setiabudi, D.H.; Wydiadana, I.G.A. Humanitarian Logistics Information System for Natural Disaster: A Case Study on East Java, under the Coordination of Indonesian Red Cross. In Proceedings of the 2019 International Conference on Information Technology and Computer Communications, Singapore, 16-18 August 2019; pp. 86-92.

56. Geumpana, T.A.; Rabhi, F.; Lewis, J.; Ray, P.K.; Zhu, L. Mobile cloud computing for disaster emergency operation: A systematic review. In Proceedings of the 2015 IEEE International Symposium on Technology and Society (ISTAS), Dublin, Ireland, 11-12 November 2015; pp. 1-8.

57. Abushaikha, I.; Schumann-Bölsche, D. Mobile phones: Established technologies for innovative humanitarian logistics concepts. Procedia Eng. 2016, 159, 191-198. [CrossRef]

58. Ma, Y.; Zhang, H. Enhancing knowledge management and decision-making capability of China's emergency operations center using big data. Intell. Autom. Soft Comput. 2017, 24, 107-114. [CrossRef]

59. Li, W.-S.; Chen, K.-H.; Chang, C.-L.; Lee, Y. Initial Use of Big Data and Open Data on Disaster Risk Management. In Proceedings of the International Conference on Information Technology in Disaster Risk Reduction, Kyiv, Ukraine, 9-10 October 2017; pp. 19-24.

60. Nagendra, N.P.; Narayanamurthy, G.; Moser, R. Management of humanitarian relief operations using satellite big data analytics: The case of Kerala floods. Ann. Oper. Res. 2020, 1-26. [CrossRef]

61. Baffoe, B.O.K.; Luo, W. Humanitarian Relief Sustainability: A Framework of Humanitarian Logistics Digital Business Ecosystem. Transp. Res. Procedia 2020, 48, 363-387. [CrossRef]

62. Dubey, R.; Gunasekaran, A.; Bryde, D.J.; Dwivedi, Y.K.; Papadopoulos, T. Blockchain technology for enhancing swift-trust, collaboration and resilience within a humanitarian supply chain setting. Int. J. Prod. Res. 2020, 58, 3381-3398. [CrossRef]

63. See, Z.S.; Blundell, D.; Thwaites, H. Virtual reality 360 content preservation for disaster relief. In Proceedings of the 2017 Pacific Neighborhood Consortium Annual Conference and Joint Meetings (PNC), Tainan, Taiwan, 7-9 November 2017; pp. 174-179. 
64. Rodríguez-Espíndola, O.; Chowdhury, S.; Beltagui, A.; Albores, P. The potential of emergent disruptive technologies for humanitarian supply chains: The integration of blockchain, Artificial Intelligence and 3D printing. Int. J. Prod. Res. 2020, 58, 4610-4630. [CrossRef]

65. Zhao, M.; Liu, X. Development of decision support tool for optimizing urban emergency rescue facility locations to improve humanitarian logistics management. Saf. Sci. 2018, 102, 110-117. [CrossRef]

66. Fraga-Lamas, P.; Fernández-Caramés, T.M. Leveraging Blockchain for Sustainability and Open Innovation: A Cyber-Resilient Approach toward EU Green Deal and UN Sustainable Development Goals. In Computer Security Threats; IntechOpen: London, UK, 2020.

67. Hrastinski, S.; Kviselius, N.Z.; Ozan, H.; Edenius, M. A review of technologies for open innovation: Characteristics and future trends. In Proceedings of the 2010 43rd Hawaii International Conference on System Sciences, Honolulu, HI, USA, 5-8 January 2010; pp. 1-10.

68. Baharmand, H.; Comes, T. Leveraging partnerships with logistics service providers in humanitarian supply chains by blockchainbased smart contracts. IFAC-Pap. Online 2019, 52, 12-17. [CrossRef]

69. Papadopoulos, T.; Gunasekaran, A.; Dubey, R.; Altay, N.; Childe, S.J.; Fosso-Wamba, S. The role of Big Data in explaining disaster resilience in supply chains for sustainability. J. Clean. Prod. 2017, 142, 1108-1118. [CrossRef]

70. Sahebjamnia, N.; Torabi, S.A.; Mansouri, S.A. A hybrid decision support system for managing humanitarian relief chains. Decis. Support Syst. 2017, 95, 12-26. [CrossRef]

71. Kroon, N.; Alves, M.d.C.; Martins, I. The Impacts of Emerging Technologies on Accountants' Role and Skills: Connecting to Open Innovation-A Systematic Literature Review. J. Open Innov. Technol. Mark. Complex. 2021, 7, 163. [CrossRef]

72. Dudnik, O.; Vasiljeva, M.; Kuznetsov, N.; Podzorova, M.; Nikolaeva, I.; Vatutina, L.; Khomenko, E.; Ivleva, M. Trends, Impacts, and Prospects for Implementing Artificial Intelligence Technologies in the Energy Industry: The Implication of Open Innovation. J. Open Innov. Technol. Mark. Complex. 2021, 7, 155. [CrossRef] 